\title{
Impact of Financial Literacy on Individual Saving: A Study in the Omani Context
}

\author{
Mohammed Ahmar Uddin ${ }^{1}$ \\ ${ }^{1}$ Department of Finance and Economics, College of Commerce and Business Administration, Dhofar University, \\ Salalah, Oman \\ Correspondence: Dr. Mohammed Ahmar Uddin, Assistant Professor, Department of Finance and Economics, College \\ of Commerce and Business Administration, Dhofar University, Salalah, Oman. E-mail: ahmar@ du.edu.om
}

Received: February 17, 2020

Accepted: August 2, 2020

Online Published: September 3, 2020

doi:10.5430/rwe.v11n5p123

URL: https://doi.org/10.5430/rwe.v11n5p123

\begin{abstract}
This exploratory study examines the effect of financial literacy (henceforward FL) on savings. A survey was conducted on 200 individuals in Oman for this study. Apart from FL, socio-demographics such as gender, age, and education were also analyzed. Data analysis was done using logistic regression. The results show that the level of FL had a significant, positive impact on individual savings. Also, demographics, such as age, educational level influenced the probability of saving positively. Results of this study advocate that it is important to increase financial literacy as it leads to more savings and thus helps in providing investment for the diversification of the Omani economy.
\end{abstract}

Keywords: financial literacy, saving, demographic, logistic regression, Oman

JEL Code: A20, D01, D14, D63, J11, 053

\section{Introduction}

As per Remund (2010) "financial literacy is a measure of the degree of which one understands key financial concepts and possesses the ability and confidence to manage personal finances through appropriate, short-term decision-making and sound, long-range financial planning, while mindful of life events and changing economic conditions." Financial literacy is the "knowledge and education about financial areas". Financial literacy helps to make an appropriate financial decision; it also helps to adopt modern technology and ways to meet current needs and demands of the world. Everyone needs to learn the basic knowledge of financial areas so that users can make an effective decision. Financial literacy helps individuals to plan for their retirement, save money for the future, and do not borrow on a high-interest rate from some financial institutions. As compared to financially literate people, individuals who do not plan for retirement face several problems such as they fail to save money for meeting their future expenses and have to borrow money from others to fulfill their needs and demands. Individuals who plan for their retirement have more money as compared to those who do not plan for their retirement. At the macro level, financial literacy affects economic growth through increased savings and investment. Nations with higher financial literacy levels had relatively higher savings and higher financial literacy in more national savings (Jappelli and Padula, 2011).

This paper tries to examine the determinants of saving in Oman with a special focus on the role of financial literacy. This research provides new empirical evidence on the key determinants of saving in Oman. The study shows that financial literacy is an important determinant of saving in Oman. Saving is also influenced by the age and the general education level. Findings support that decision to save increases with the financial literacy level, age, and education of individuals. Increased literacy gives individuals better control of their present and future finances. Since there is no known research this study can be regarded as an exploratory study in the context of Oman.

\section{Literature Review}

Researchers across the world such as Cole, et al. (2011) in Indonesia, Bruhn, et al. (2013) in Brazil, Prusty (2011) in India, Mahdzan and Tabiani (2013) in Malaysia, Murendo and Mutsonziwa (2017) in Zimbabwe and Lusardi and Mitchell, (2014) in the USA, have studied the impact of financial literacy and demographics on savings. People must know about insurance, investment, and savings so that they can make a better financial decision. Financial literacy positively affects individual savings and also helps in the management of money. It has been observed that financially literate people have a better knowledge of technology and skills, at the same time they are well aware of 
the management of money. Such people also understand the way of maintenance of financial position. The saving behavior of individuals has great effectiveness as it directly contributes to the development and growth of the economy and also provides long term investment for the welfare of the country. The high saving rate plays an effective role in the development of the economy and also determines that the economy of a country is in good condition. The behavior of individuals not only contributes to the development of the economy but also provides great benefits for the individual itself. Financially literate people save money by using different services offered by financial institutes (Beal Delpachtra, 2017). There is a great need to educate people by providing financial education so that they can get benefit by using any services offered by financial institutions and meet their future needs and demands (Gottschalck, 2016). Every individual should improve financial literacy, for this purpose people can use different resources such as by reading newspapers, magazines, and internet browsing, people can improve their financial literacy skills. The positive aspects of savings have been highlighted in various studies such as Tang, Chua, 2009. Government and financial institution should arrange a financial literacy class for improvement of the general public, it not only improves the saving rate but also helps the country by boosting economic growth (Cheng, 2018).

Financial literacy plays an effective role in increasing savings. Saving assist countries in enhancing productivity and economic growth, thus avoiding recessions. Financial literacy help individual in managing financial matters regarding insurance, investment, and savings. It helps to understand financial matters and enhance their analytical skills. It also persuades individuals to improve their skills and knowledge about financial matters and understand the importance of financial products and services. Babiarz \& Robb (2014) found that households with higher financial literacy are more likely to save for an emergency. Morgan \& Long (2020) surveyed in 8 states of Loas using multilevel stratification sampling. Their study also found that financial literacy has positive effects on savings.

In India, the level of financial literacy of working persons between 50-55 years, and their savings behavior were studied by Prusty (2011); financial literacy was found to be a significant determinant of household savings. The effect of financial literacy on the personal savings of students and residents in Malaysia was analyzed using probit regression by Mahdzan and Tabiani (2013). They showed that financial literacy was a significant positive determinant of individual savings. Jappelli and Padula (2013) examined the effect of financial literacy on savings for the aged population and also found that financial literacy raised the savings. They found that and a unit increase in financial literacy results in 3.6 times increases in the national savings. Murendo and Mutsonziwa (2017) in Zimbabwe used probit regression to show that there is a positive relationship between financial literacy and personal savings. Baidoo, Boateng, \& Amponsah (2018) using probit regression showed that financial literacy can be an important instrument in encouraging savings in Ghana. Contrarily, Garcia and Vila (2020) conducted a field experiment on employees of a pensions company in Spain and found that higher financial literacy does not always result in more savings. They have suggested that nudging is necessary as it propels individuals to take definite actions related to savings.

Concerning the demographic and savings, gender, age, income, and education are found to influence savings. (Lusardi and Mitchell, 2007; Mahdzan and Tabiani, 2013). Bhushan \& Medury, (2013), ING Group, (2011), Taylor, (2011) \& Lusardi et al., (2010) found in their studies that financial literacy gets affected by demographic characteristics (gender, education, income, employment type and place of work). People with higher knowledge of finance are better at understanding savings and insurance plans. In Vietnam, the savings behavior was studied by Tuong \& Doan (2020). They surveyed 692 respondents and used the binary regression results to analyses the data. Their findings showed that financial literacy has a positive influence on savings and as compared to men; women are more likely to save. However, the details of how learning affects the saving and investment decisions are not clear (Maki, 2004).

As most of the researches on financial literacy and saving has been carried out abroad, consequently for Oman there is a lack of research. Due to a lack of prior research in Oman, there exists a research gap. This study focuses on the impact of financial literacy on individual savings in Oman and can help fulfill this gap.

\section{Research Methodology}

The objective of this paper was to analyze the effect of financial literacy and demographic variables on personal savings. Data was collected using a questionnaire through a convenience sampling method since it is an exploratory study aimed to provide preliminary knowledge on the issues being examined. 200 complete and usable questionnaires were collected. The process lasted for three months from March to June 2019. Logistic regression was used to analyze the data. Previous studies such as Tuong \& Doan (2020) and Baidoo, Boateng, \& Amponsah (2018) have also used the same methodology. S\&P Global Financial Literacy quiz (refer to appendix) was used to ascertain the level of financial literacy of the respondents. The dependent variable is individual saving, while the independent variables are financial literacy, gender, age, and education. (Table 1) 
Table 1. Data description

\begin{tabular}{ll}
\hline Saving & $\begin{array}{l}\text { Personal saving (It takes } 1 \text { or } 2 \text { ) The dependent variable is individual saving, which is measured as } \\
\text { a binary variable, where } 2 \text { indicates having positive saving, and } 1 \text { indicates no saving }\end{array}$ \\
\hline Financial literacy & $\begin{array}{l}\text { Individual financial literacy level (It takes a value between } 0 \text { and } 5 . \text { A higher score means higher } \\
\text { financial literacy level.) }\end{array}$ \\
\hline Gender & Female $=1 ;$ Male $=2$ \\
\hline Age (in years) & $\leq 30=1 ; 31$ to $40=2 ; 41$ to $50=3 ; \&>51=4$ \\
\hline Education & Up to Diploma $=1 ;$ Graduate $=2$ \\
\hline
\end{tabular}

\subsection{Method}

This study explores the effect of financial literacy and demographic variables on the savings of an individual. The logistic regression analysis is used because the dependent variable (SAVING) is a binary variable. The equation for logistic regression is given as (Table 2).

Table 2. Equation for logistic regression

$$
P(\mathrm{~S})=1 /\left\{1+e-\left(b_{0}+b_{1} X_{1 i}+b_{2} X_{2 i}+\cdots+b n X_{n i}\right)\right\}
$$

Where " $\mathrm{P}(\mathrm{S})$ is the probability of saving; $\mathrm{X}_{\mathrm{i}}$ predictor variable; $b_{i}$ coefficient of predictor variable; $e$ is the base of natural logarithms and $\mathrm{b}_{0}$ is a constant".

\section{Results}

Table 3 shows descriptive findings. While Tables 4, 5 and 6 show the results of logistic regression.

Table 3. Descriptive

\begin{tabular}{|c|c|c|c|c|c|c|c|}
\hline \multirow{2}{*}{\multicolumn{2}{|c|}{ Cross Tabulations }} & \multicolumn{4}{|c|}{ Saving } & \multirow[b]{2}{*}{ Total } & \multirow[t]{2}{*}{ Remarks } \\
\hline & & No Saving & $\begin{array}{l}\text { Percenta } \\
\text { Savings }\end{array}$ & Savings & $\begin{array}{l}\text { Percentage } \\
\text { Savings }\end{array}$ & & \\
\hline \multirow{5}{*}{$\begin{array}{l}\text { Financial } \\
\text { Literacy } \\
\text { Score }\end{array}$} & 1.00 & 39 & 97.5 & 1 & 2.50 & 40 & \multirow{5}{*}{$\begin{array}{l}\text { The maximum percentage of savings } \\
\text { was done by respondents with } \\
\text { financial literacy score of } 4 \text {. }\end{array}$} \\
\hline & 2.00 & 15 & 25 & 45 & 75.00 & 60 & \\
\hline & 3.00 & 9 & 17.31 & 43 & 82.69 & 52 & \\
\hline & 4.00 & 1 & 3.13 & 31 & 96.87 & 32 & \\
\hline & 5.00 & 3 & 18.75 & 13 & 81.25 & 16 & \\
\hline \multirow[b]{2}{*}{ Gender } & Female & 30 & 56.61 & 23 & 43.39 & 53 & \multirow{2}{*}{$\begin{array}{l}\text { There were } 53 \text { females and } 147 \text { males. } \\
43.39 \% \text { females and } 74.82 \% \text { males } \\
\text { were saving. }\end{array}$} \\
\hline & Male & 37 & 25.18 & 110 & 74.82 & 147 & \\
\hline \multirow{4}{*}{ Age } & $\leq \mathbf{3 0}$ & 30 & 66.67 & 15 & 33.33 & 45 & \multirow{4}{*}{$\begin{array}{l}\text { The percentage of respondents saving } \\
\text { - increases age-wise. } 97.36 \% \text { of } \\
\text {-persons aged above } 51 \text { years are }\end{array}$} \\
\hline & 31 to 40 & 18 & 31.04 & 40 & 68.96 & 58 & \\
\hline & 41 to 50 & 18 & 30.51 & 41 & 69.49 & 59 & \\
\hline & $>51$ & 1 & 2.64 & 37 & 97.36 & 38 & \\
\hline \multirow[b]{2}{*}{ Education } & Up to Diploma & 62 & 43.98 & 79 & 56.02 & 141 & \multirow{2}{*}{$\begin{array}{l}\text { The percentage of respondents saving } \\
\text { increases with education. } 91.52 \% \text { of } \\
\text { respondents having qualification } \\
\text { above diploma are saving. }\end{array}$} \\
\hline & Above Diploma & 5 & 8.48 & 54 & 91.52 & 59 & \\
\hline Total & & 67 & 33.5 & 133 & 66.5 & 200 & Overall $66.5 \%$ are saving. \\
\hline
\end{tabular}


The model summary, Classification Table and results of logistic regression are shown in Tables 4, 5 and 6 .

Table 4. Model Summary

\begin{tabular}{llcr}
\hline Step & -2 Log likelihood & Cox \& Snell R Square & \multicolumn{2}{c}{ Nagelkerke R Square } \\
\hline 1 & $160.396^{\mathrm{a}}$ & 0.377 & \\
\hline
\end{tabular}

a. Estimation terminated at iteration number 6 because parameter estimates changed by less than .001 .

Table 5. Classification table

\begin{tabular}{|c|c|c|c|c|}
\hline & \multicolumn{3}{|c|}{ Predicted Saving } & \multirow[b]{2}{*}{ Percentage Correct } \\
\hline \multirow[t]{3}{*}{ Observed } & & No Savings & Savings & \\
\hline & No Savings & 43 & 24 & 64.2 \\
\hline & Savings & 18 & 115 & 86.5 \\
\hline Overall & ercentage & & & 79.0 \\
\hline
\end{tabular}

a. The cut value is .500

Table 6. Results of Logistic Regression

\begin{tabular}{llllll}
\hline & B & S.E. & Wald & Sig. & $\operatorname{Exp(B)}$ \\
\hline Financial Literacy Score & .976 & .227 & 18.413 & .000 & 2.654 \\
\hline Gender & .698 & .484 & 2.076 & .150 & 2.010 \\
\hline Age & .832 & .221 & 14.152 & .000 & 2.298 \\
\hline Education & 1.119 & .563 & 3.944 & .047 & 3.061 \\
\hline Constant & -6.059 & 1.107 & 29.952 & .000 & .002 \\
\hline
\end{tabular}

*significance at $0.05 ; * *$ significance at 0.01

The results of the logistic regression show that the independent variables can predict between $37.7 \%$ and $52.3 \%$ of the variance in savings. The classification table showed that our model can predict $64.2 \%$ of not saving and $86.5 \%$ of saving, while the overall correct predictions are $79 \%$.

Financial Literacy Score and age are significant at 1 percent while education is significant at 5 percent. Higher Financial Literacy Score has a positive effect on savings. Respondents with high Financial Literacy scores are 2.6 times more likely to save. There is no effect of gender on savings. Age has a positive effect on savings. Respondents who had a higher age were 2 times more likely to save. Education also has a positive effect on savings. Respondents having higher education were 3 times more likely to save.

The results of the logistic regression show that the independent variables can predict between $37.7 \%$ and $52.3 \%$ of the variance in savings. The classification table showed that our model can predict $64.2 \%$ of not saving and $86.5 \%$ of saving, while the overall correct predictions are $79 \%$.

\section{Conclusion and Recommendations}

This study highlights the significance of financial literacy and savings for Oman. The results show that financially literate persons have a greater probability of saving. A rise in financial literacy will result in more savings. It is increasingly necessary for an individual to get proper knowledge about financial products and services. An individual must have adequate knowledge so that he can administer his finances easily and correctly. Most people do not have much information about financial products and services; therefore, they are unable to enjoy the benefits associated with these products and services. Today, financial literacy directly related to household welfare. People who have good knowledge about financial products and services plan better to save their earnings. Many countries, in particular, the European Union countries and the United States, are trying to advance financial literacy by introducing financial education at the level of primary education and educating adults through different programs. 
The study will help policy-makers to endorse schemes for the individuals which will ensure that individuals are cognizant of financial issues. The government and financial institutions should make efforts collectively to provide financial education across the country. It not only helps in reducing poverty but also improves well-being. Financial literacy also helps in planning, decision making, and management of life. The findings of the study will also help researchers as it supplements the existing literature on financial literacy, saving, and demographics.

This theme is a comparatively new topic in Oman; therefore, this area can be further investigated. Future investigations can focus on how the involvement of people in savings can be increased. The limitation of this study is that non-respondents may probably be uncomfortable in discussing financial matters, and therefore, declined to fill the questionnaire. Thus, the results reflect the response from more knowledgeable persons. So the actual financial literacy may be lower than what is suggested by the study.

\section{References}

Babiarz, P., \& Robb, C. A. (2014). Financial literacy and emergency saving. Journal of Family and Economic Issues, 35(1), 40-50. https://doi.org/10.1007/s10834-013-9369-9

Baidoo, S. T., Boateng, E., \& Amponsah, M. (2018). Understanding the determinants of saving in Ghana: Does financial literacy matter?. Journal of International Development, 30(5), 886-903. https://doi.org/10.1002/jid.3377

Beal, D. J., \& Delpachtra, S. B. (2003). Financial Literacy among Australian University Students. Economic Papers, 22(1), 65-78. https://doi.org/10.1111/j.1759-3441.2003.tb00337.x

Bhushan, P., \& Medury, Y. (2013). Financial Literacy and its Determinants. International Journal of Engineering, Business and Enterprise Applications, 4(2), 155-160. Retrieved from http://iasir.net/IJEBEApapers/IJEBEA13-145.pdf

Bruhn, M., de Souza Leão, L., Legovini, A., Marchetti, R., \& Zia, B. (2013). The Impact of High School Financial Education. Experimental Evidence from Brazil. World Bank Policy Research Working Paper 6723.

Cole, S., Sampson, T., \& Zia, B. (2011). Price or Knowledge? What Drives Demand for Financial Services in Emerging Markets?. The Journal of Finance, 66(6), 1933-1967. https://doi.org/10.1111/j.1540-6261.2011.01696.x

Garcia, J. M., \& Vila, J. (2020). Financial literacy is not enough: The role of nudging toward adequate long-term saving behavior. Journal of Business Research. https://doi.org/10.1016/j.jbusres.2020.01.061

Gottschalck, A. O. (2008). Net Worth and the Assets of Households: (2002). Current Population Reports, Washington, DC, U.S., Census Bureau, pp.70-115.

Hastings, J. S., Brigitte, C. M., \& William, L. S. (2013). Financial Literacy, Financial Education, and Economic Outcomes. Annual Review of Economics, 2013, 347-73.

ING-International Financial literacy and Consumer Resourcefulness study. (2011). Retrieved from https://cz.nnfondy.eu/document/14097/2011\%20Summary\%20ING\%20consumer\%20resourcefulness\%20 study.pdf

Jappelli, T., \& Padula, M. (2011). Investment in Financial Literacy and Saving Decisions. Retrieved November 20, 2016, from http://voxeu.org/article/investment-financial-literacy-and-saving-decisions

Lusardi, A., \& Olivia, S. M. (2007). Financial Literacy and Retirement Preparedness: Evidence and Implications for Financial Education. Business Economics, 35-44. https://doi.org/10.2145/20070104

Lusardi, A., \& Olivia, S. M. (2014). The Economic Importance of Financial Literacy: Theory and Evidence. Journal of Economic Literature, 52, 5-44. https://doi.org/10.1257/jel.52.1.5

Lusardi, A., Olivia, S. M., \& Vilsa, C. (2010). Financial Literacy Among the Young. Journal of Consumer Affairs, 44(2), 358-380. https://doi.org/10.1111/j.1745-6606.2010.01173.x

Mahdzan, N. S., \& Tabiani, S. (2013). The Impact of Financial Literacy on Individual Saving: An Exploratory Study in the Malaysian Context. Transformations in Business \& Economics, 12(1), 41-55. https://doi.org/10.1108/jabes-12-2019-0120

Maki, D. (2004). Financial Education and Private Pensions. In W. Gale, J. Shoven, \& M. Warshawsky (Eds.), Private Pensions and Public Policies (pp. 126-139). Washington, DC: Brookings Institution Press.

Morgan, P. J., \& Long, T. Q. (2020). Financial Literacy, Financial Inclusion, and Savings Behavior in Laos. Journal of Asian Economics, 101197. https://doi.org/10.1016/j.asieco.2020.101197 
Murendo, C., \& Mutsonziwa, K. (2017). Financial literacy and savings decisions by adult financial consumers in Zimbabwe. International Journal of Consumer Studies, 41(1), 95-103. https://doi.org/10.1111/ijcs.12318

Prusty, S. (2011). Household Saving Behaviour: Role of Financial Literacy and Saving Plans. Journal of World Economics Review, 6(1), 75-86.

Remund, D. L. (2010). Financial Literacy Explicated: The Case for a Clearer Definition in an Increasingly Complex Economy. Journal of Consumer Affairs, 44, 276-295. https://doi.org/10.1111/j.1747-6606.2010.01169.x

Tang, C. F., \& Chua, S. Y. (2009). The Saving-Growth Nexus in Malaysia: Evidence from Nonparametric Analysis. The IUP Journal of Financial 94 Economics, VII(3-4), 83-94.

Taylor, M. (2011). Measuring Financial Capability and Its Determinants Using Survey. Social Indicator Research, Springer Science, 102(2), 297-31417. Retrieved from https://eric.ed.gov/?id=EJ919849

Tuong, V., \& Doan, M. D. (2020). The Correlation between Financial Literacy and Personal Saving Behavior in Vietnam. Asian Economic and Financial Review, 10(6), 590-603. https://doi.org/10.18488/journal.aefr.2020.106.590.603

\section{Copyrights}

Copyright for this article is retained by the author(s), with first publication rights granted to the journal.

This is an open-access article distributed under the terms and conditions of the Creative Commons Attribution license (http://creativecommons.org/licenses/by/4.0/). 